\title{
KONSEP BUDAYA BATAK DALAM FILM MURSALA SUTRADARA VIVA WESTI (ANALISIS SEMIOTIKA)
}

\author{
Sri Wahyuni \\ Prodi Televisi dan Film \\ Fakultas Seni dan Desain Universitas Potensi Utama \\ Sriwahyuni2909@gmail.com
}

\begin{abstract}
ABSTRAK
Penelitian ini bertujuan untuk mengungkap konsep budaya batak pada masyarakat dalam film Mursala serta mengungkap pandangan masyarakat khususnya masyarakat batak terhadap film Mursala karya Viva Westi. Metode yang digunakan dalam penelitian ini berbentuk kualitatif. Kerangka teoritis dibangun berdasarkan data yang di dapat dari lapangan kemudian disesuaikan dengan objek penelitian yaitu film Mursala. Untuk melihat kesesuaian antara realitas yang ada pada masyarakat maka digunakan teori Semiotika Roland Barthes yang mengungkap berdasarkan penanda, petanda dan mitos serta teori resepsi Hans Robert Jauss dam Wolfgang Iser untuk mengetahui pandangan masyarakat terhadap film Mursala. Hasil yang diperoleh dalam penelitian bahwa terdapat mitos-mitos pada masyarakat Batak sehingga membuat masyarakat tersebut mengikuti tradisinya. Konsep budaya dimunculkan dalam film Mursala melalui penanda dan petanda dan membentuk mitos yang bermakna pewarisan tradisi. Tradisi tersebut menggambarkan sistem kekerabatan pada masyarakat Batak yaitu Dalihan Na Tolu. Kekerabatan tersebut seperti larangan menikah semarga pada masyarakat Batak dan telah diwariskan secara turun temurun.
\end{abstract}

Kata Kunci: Konsep Budaya Batak, Film Mursala

\begin{abstract}
This study aims to uncover the concept of Batak culture in the community in the film Mursala and reveal the views of the community, especially the Batak people, towards the film Mursala by Viva Westi. The method used in this study is qualitative. The theoretical framework is built based on the data obtained from the field and then adjusted to the object of research, namely the film Mursala. To see the compatibility between the realities that exist in society, Roland Barthes's Semiotic theory is used which reveals based on markers, markers and myths and reception theory Hans Robert Jauss and Wolfgang Iser to find out the views of the public about the film Mursala. The results obtained in the study that there are myths in the Batak people that made the community follow its tradition. Cultural concepts appear in the film Mursala through markers and markers and form myths that mean inheritance of tradition. This tradition describes the kinship system in the Batak community, namely Dalihan Na Tolu. Such kinship is like a ban on marrying as high as the Batak people and has been passed down from generation to generation.
\end{abstract}

Keywords: Concept of Batak Culture, Mursala Film

\section{PENDAHULUAN}

Batak merupakan salah satu suku bangsa Indonesia yang sejak dulu hingga sekarang menjunjung tinggi adat dan nilai kekeluargaan (kekerabatan) serta rasa solidaritas. Sifatsifat mereka yang khas, gaya dan kepribadiannya merupakan gambaran yang melukiskan secara keseluruhan kehidupan suku Batak, baik di daerah perantauan maupun di daerah 
asal. Kebiasaan gotong royong yang diajarkan di lingkungan keluarga menjadikan sifat keuletan, kerja keras dan kesungguhan mencerminkan kepribadian yang ada di dalam diri mereka.

Konsep yang sangat mendasar dari sistem kekerabatan ini adalah marga. Semua anggota dari satu marga memakai satu identitas yang dibubuhkan sesudah nama kecilnya, nama marga itu merupakan pertanda bahwa orang-orang yang menggunakannya masih mempunyai kakek yang sama. Secara logis tidak dapat diperinci rentetan leluhur atau kakek yang menghubungkan orang-orang se-marga dengan kakek yang sama, namun ada suatu keyakinan bahwa orang-orang yang menggunakan nama marga tersebut terjalin oleh hubungan darah. Penentuan kedudukan yang ditimbulkan berdasarkan marga membuat seseorang akan terikat kepada adat istiadat yang disebut dengan Dalihan Na Tolu (Tungku nan Tiga).

Sistem kekerabatan Dalihan Na Tolu (Tungku nan Tiga) mengatur kehidupan orangorang Batak sehingga menjadikan suku Batak sangat khas. Dalihan Na Tolu terdiri dari 3 (tiga) unsur atau bagian yang merupakan suatu kesatuan yang tidak dapat dipisahkan. Pertama Hula-Hula merupakan kelompok orang-orang yang posisinya di atas, terdiri dari keluarga marga pihak istri sehingga disebut somba marhula-hula yaitu harus hormat kepada keluarga pihak istri agar memperoleh keselamatan dan kesejahteraan. Kedua Dongan Sabutuha yaitu kelompok orang-orang yang posisinya sejajar seperti teman atau saudara semarga sehingga disebut manat mardongan tubu artinya menjaga persaudaraan agar terhindar dari perseteruan. Ketiga boru yaitu kelompok orang-orang yang posisinya di bawah seperti saudara perempuan dan pihak marga suaminya, keluarga perempuan pihak ayah sehingga dalam kehidupan sehari-hari disebut elek marboru artinya untuk selalu saling mengasihi agar mendapat berkat.

Setiap acara adat istiadat masyarakat Batak memiliki perannya masing-masing sesuai dengan Dalihan Na Tolu, hal ini dapat dilihat saat masyarakat Batak mengadakan acaraacara adat seperti pernikahan, memasuki rumah baru dan lain sebagainya. Peran dalam Dalihan Na Tolu akan menjadi tumpang tindih atau tidak jelas jika ada perkawinan semarga yang mengakibatkan pihak perempuan tidak bisa menentukan mana pihak Parboru ( saudara perempuan) dan pihak Paranak pada setiap acara adat termasuk acara adat perkawinan. Maka, Salah satu konsekuensi dari Dalihan Na Tolu adalah larangan menjalin ikatan perkawinan atau pernikahan bagi perempuan dan laki-laki yang mempunyai marga yang sama.

Aturan ini berdasarkan namarpadan/padan atau ikrar janji yang sudah ditetapkan oleh marga-marga tertentu, selain itu laki-laki dan perempuan tidak bisa saling menikah yang padan marga yaitu yang memiliki marga yang sama (subang ${ }^{2}$ ) dan bagi suku Batak pernikahan ideal adalah menikah dengan anak perempuan dari saudara laki-laki ibu (tulang) (matrilateral cross cousin) yang disebut dengan istilah pariban. Aturan-aturan ini harus ditaati dan jika terjadi pelanggaran hukumannya sangat tegas (Vergouwen,1986: iv).

Konsep Batak itu sendiri digambarkan dalam film Mursala. Mursala diambil dari nama sebuah pulau terbesar di wilayah Kabupaten Tapanuli Tengah yaitu pulau Mursala. Pulau ini termasuk wilayah Kecamatan Barus, Tapanuli Tengah dan terletak disebelah Barat Daya Kota Sibolga. Mursala dijadikan sebuah film yang berdurasi sekitar satu jam tiga

\footnotetext{
${ }^{1}$ Marga adalah kelompok orang-orang yang merupakan keturunan dari seorang kakek yang bersama dan garis keturunannya dihitung melalui bapak (bersifat patrilineal) Vergouwen J : 1986.

${ }^{2}$ Subang adalah pantangan dalam suku Batak (Vergouwen J: 1986)..
} 
puluh menit enam detik (https://id.m.wikipedia.org/wiki/Mursala (film) diakses pada tanggal 16 Februari 2017 pukul 16.40). Film Mursala menampilkan keindahan Kabupaten Tapanuli Tengah yang memiliki Brand Image "Negeri Wisata Sejuta Pesona", terbukti dari banyaknya tempat-tempat yang menjadi lokasi syuting proses pembuatan film Mursala di daerah tersebut.

Fenomena yang disampaikan dalam cerita film Mursala menjadi sangat menarik untuk dikaji lebih lanjut. Ketika cerita pada film Mursala dikaitkan langsung dengan realitas yang terjadi pada masyarakat Batak pada saat ini mengenai adanya larangan pernikahan dari leluhur Batak bahwa beberapa marga telah mengikat janji untuk tidak saling menikah. Berdasarkan fenomena larangan pernikahan pada adat Batak yang terdapat dalam realita film dan menghubungkan dengan fenomena masyarakat Batak maka film ini menarik untuk diteliti lebih lanjut.

\section{STUDI LITERATUR}

Beberapa tulisan yang telah dijadikan rujukan atau referensi penulis dalam penelitian ini adalah sebagai berikut:

Tulisan Virani Indiarma (2013) dalam tesisnya yang berjudul: "Representasi Nilai Posfeminisme dalam Film Nasional (Analisis Semiotika Tentang Nilai Posfeminisme Pada Film Mereka Bilang Saya Monyet!)". Tesis ini menjelaskan Era postmodern telah ikut mengubah wajah perempuan dalam media, yang semula dalam film modern menjadi objek hasrat berganti menjadi subjek hasrat, seperti dalam film Mereka Bilang Saya Monyet!. Pergeseran tersebut sangat mengesankan adanya nilai-nilai posfeminisme dalam film. Namun, ketidaksadaran patriarkal terus 'bekerja', sehingga perlu dicermati lagi perempuan direpresentasikan dalam film Mereka Bilang Saya Monyet!. Analisis semiotika Roland Barthes dipilih karena mampu menjangkau tidak hanya pada level teks, maupun simbol namun juga menggunakan satu tema lagi dalam pembacaan tanda, yaitu mitos. Mengkaji tanda dengan menggunakan mitologi Barthes tidak lagi diharuskan membedah penanda dan petanda pada level linguistik secara terpisah, cukup mengetahui makna denotatif secara global karena dari tanda denotatif inilah mitos dibicarakan. Beranjak dari mitos inilah kemudian dapat memposisikan suatu tanda berada dalam ranah ideologis tertentu.

Hasil penelitian ini kemudian menunjukkan bahwa film Mereka Bilang Saya Monyet! tidak memiliki perbedaan dengan film-film era modern. Tidak ada penggambaran perempuan yang dapat mengantarkan penonton perempuan dalam kesenangan melihat atau hasrat yang bebas dalam film tersebut, sebagaimana yang diajukan dalam nilai-nilai posfeminisme. Film ini secara jelas hanya mengulang narasi klasik yang ada dalam filmfilm modern. Film tersebut tidak ada penggambaran perempuan yang otonom, bebas, berani memilih jalannya sendiri dan bahagia dalam pilihan itu. Temuan dalam hasil penelitian menunjukkan anti tesis yang menggambarkan film Mereka Bilang Saya Monyet! sebagai film yang hanya menawarkan label baru namun tetap dengan fenomena lama. Tidak berbeda dengan sinema feminis modern yang berakhir pada penggambaran perempuan yang lemah dan karenanya selalu menjadi objek penderitaan. Persamaannya dengan penelitian ini yakni sama-sama mengkaji film dan menggunakan semiotika Roland Barthes. Perbedaannya pada objek film, yang mana tesis Virani Indiarma mengkaji sebuah film “Mereka Bilang Saya Monyet!" sedangkan penelitian yang akan dilakukan ini adalah mengkaji Konsep budaya batak dalam realitas Masyarakat Batak dan Film Mursala Karya Viva Westi. 
Penelitian David Andrian H. Siahaan dan Indri fogar Susilowati, SH., MH (tanpa tahun) yang berjudul "Akibat Perkawinan Semarga Menurut Hukum Adat Batak Toba". Penelitian ini mengungkap bahwa Masyarakat adat Batak Toba yang sistem kekerabatannya patrilineal dan sistem perkawinan eksogami memiliki ketentuan adat istiadat yang masih satu marga dilarang untuk melakukan perkawinan, karena perkawinan yang mereka lakukan itu masih memiliki hubungan darah atau satu nenek moyang. Maka dari itu perkawinan yang diperbolehkan dalam masyarakat adat Batak Toba adalah perkawinan beda marga atau perkawinan dengan marga lain yang tidak mempunyai hubungan kekerabatan. Alasan yang menjadi dasar dari perkawinan se-marga yang dilarang dalam masyarakat adat Batak Toba adalah hubungan kekerabatan yang ada dalam masyarakat adat Batak Toba secara umum adalah ayah, ibu, saudara ayah, saudara ibu, kakek, nenek. Namun dalam masyarakat adat Batak Toba kekerabatan itu mempunyai arti yang lebih luas lagi dengan keluarga lain dari ikatan sedarah yang disebut dengan Dalihan $\mathrm{Na}$ Tolu dan untuk menjaga partuturan yang ada dalam masyarakat adat Batak Toba. Tutur merupakan bagian dari kekerabatan dalam masyarakat adat Batak Toba, maka dari itu tutur dipergunakan untuk menentukan posisi seseorang dalam sistem Dalihan $\mathrm{Na}$ Tolu. Persamaan dalam penelitian ini sama-sama membahas mengenai objek yang sama mengenai pernikahan yang dilarang dalam masyarakat Batak khususnya Batak Toba, tetapi dalam penelitian ini memfokuskan kepada hukum adat Batak Toba sedangkan penulis membahas mengenai konsep budaya batak dalam realitas masyarakat Batak Toba dengan melihat film Mursala.

Skripsi Evalina (2007) yang berjudul "Perkawinan Pria Batak Toba dan Wanita Jawa di Kota Surakarta serta Akibat Hukumnya dalam Pewarisan”. Penelitian ini menemukan bahwa masyarakat Batak Toba pada umumnya melakukan perkawinan jujur dengan sistem perkawinan eksogami. Dalam pelaksanaan perkawinan ini berdasarkan prinsip Dalian $\mathrm{Na}$ Tolu. Prinsip ini juga dipergunaka oleh masyarakat Batak Toba yang berada di Surakarta dan begitu juga yang menikah dengan wanita Jawa. Sebelum mengadakan perkawinan terlebih dahulu wanita Jawa tersebut diberi marga untuk dapat melaksanakan pernikahan secara adat Batak Toba. Akibat perkawinan beda suku ini membawa pergeseran pada sistim pewarisan terhadap sistem kekerabatan patrilineal yang mengarah kepada sistem kekerabatan parental.

Tujuan perkawinan untuk mengetahuai pelaksanaan perkawinan antar suku dan akibat hukum bagi pewarisan terhadap anaknya. Penelitian ini menggunakan metode pendekatam yuridis empiris, yang memberikan kerangka pembuktian atau kerangka pengujian untuk memastikan suatu kebenaran, maksud adalah suatu pendekatan yang digunakan untuk menjadi acuan dalam menyoroti permasalahan pelaksanaan perkawinan antar suku dan akibat hukumnya dalam pewarisan dan teknik sampling yang digunkan dalam penelitian ini adalah non random sampling dengan teknik purposive sampling maksudnya tidak semua populasi keseluruhan. Masyarakat Batak di Surakarta masih memegang teguh Dalihan $\mathrm{Na}$ Tolu, terbukti di dalam perkawinan dengan pembayaran jujur (sinamot). Dalam melaksanakan perkawinan adat Batak memerlukan beberapa tahapan yang harus dilaksanakan oleh pasangan yang mau menikah. Begitu juga pasangan yang menikah beda suku, dalam hal ini pria Batak dan wanita Jawa. Tahap-tahap tersebut secara garis besar : tahap pemberian marga bagi si wanita Jawa dan tahap perkawinan. Perkawinan beda suku tersebut mengalami pergeseran pemikiran pemberian warisan yang semula diberikan kepada anak laki-laki, sekarang pemberian warisan bukan saja anak laki-laki tetapi juga anak perempuan. Perubahan sistem pewarisan yang semula patrilineal menjadi parental, pergeseran ini dipengaruhi kebudayaan setempat dan agama.

Persamaannya dengan penelitian ini terletak pada kajian pada masyarakat Batak. Penelitian ini juga memiliki kontribusi yang besar sebagai referensi dalam meneliti sistem 
kekerabatan Dalihan Na tolu dan mengarah pada konsep budaya batak tetapi penelitian ini memfokuskan kepada pewarisan harta pada suku Batak sedangkan perbedaannya dengan penulis terletak pada objek yaitu film Mursala yang bercerita mengenai larangan menikah masyarakat Batak dan realitas yang tergambar pada film tersebut hingga saat ini.

\section{PEMBAHASAN}

Film merupakan produk kebudayaan manusia yang dianggap berdampak besar bagi masyarakat karena merupakan salah satu bentuk seni, sumber hiburan dan alat yang ampuh untuk mendidik serta mengindoktrinasi para penontonnya. Melalui pengalaman mental dan budaya yang dimilikinya, penonton berperan aktif secara sadar maupun tidak sadar untuk memahami sebuah film (Pratista, 2008: 3). Film dapat berdampak negatif maupun positif terhadap penontonnya, Irawanto menyatakan bahwa:

Banyak penelitian film dipahami secara linier, artinya film selalu mempengaruhi dan membentuk masyarakat berdasarkan muatan pesan (message) di baliknya, tanpa pernah berlaku sebaliknya. Kritik yang muncul terhadap perspektif ini didasarkan atas argumen bahwa film adalah potret masyarakat dimana film itu dibuat. Film selalu merekam realitas yang tumbuh dan berkembang dalam masyarakat, dan kemudian memproyeksikannya ke atas layar ( Sobur, 2009: 127).

Realitas yang tumbuh dan berkembang dalam masyarakat Batak telah diproyeksikan kepada film Mursala karya Viva Westi yang bercerita mengenai seseorang yang tidak dapat menikah karena parpadanan (perjanjian) oleh para leluhur dalam adat Batak. Film Mursala dapat mempengaruhi dan membentuk pola pikir masyarakat Batak dengan pesan yang terdapat dalam film tersebut. Film Mursala dibentuk oleh dua unsur pembentuk film yaitu : unsur naratif dan unsur sinematik. Pratista menyatakan bahwa kedua unsur tersebut saling berinteraksi dan berkesinambungan satu sama lain untuk membentuk sebuah film. Film tidak akan terbentuk jika tidak memiliki kedua unsur tersebut, dapat dikatakan bahwa unsur naratif adalah bahan atau materi yang akan diolah, sedangkan unsur sinematik adalah cara dan gaya untuk mengolahnya. Berikut merupakan bagan dari unsur pembentuk film:

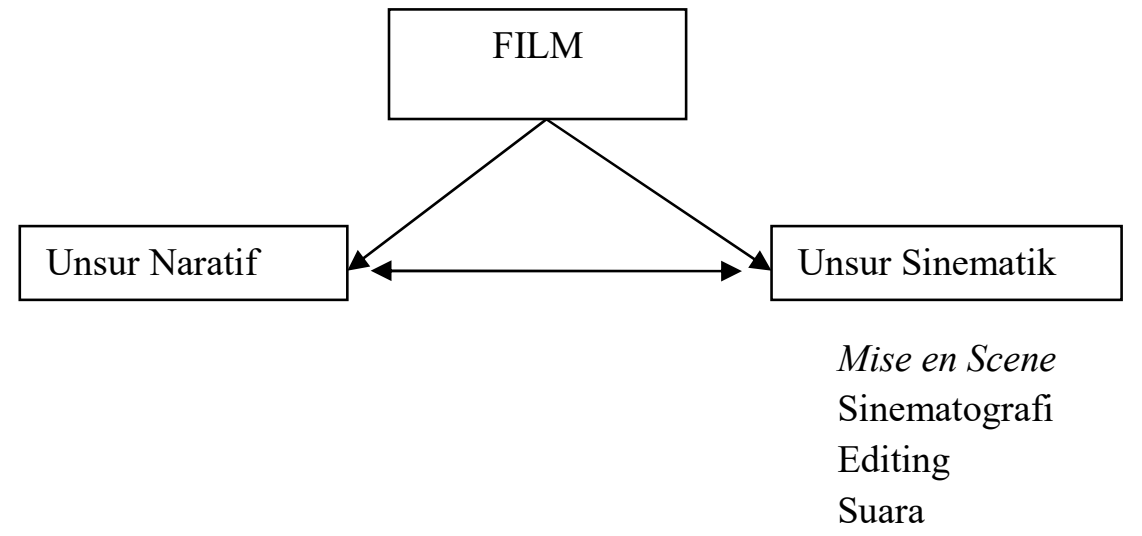

Gambar 1. Hubungan Film dengan Unsur Naratif dan Sinematik

(Sumber : Pratista, 2008) 
Bagan pada gambar 3 menjelaskan hubungan film dengan unsur naratif dan unsur sinematik. Kedua unsur tersebut dapat diuraikan sebagai berikut:

\section{A. Unsur Naratif}

Cerita sebuah film mengandung unsur naratif dalam bentuk rangkaian peristiwa yang saling berhubungan satu sama lain dan terkait logika sebab akibat (kausalitas) yang terjadi dalam ruang dan waktu. Cerita pada Film Mursala memunculkan akibat aksi, tindakan dari pelaku cerita yang memotivasi terjadinya kesatuan peristiwa yang memuat unsur-unsur plot. Plot merupakan rangkaian peristiwa yang disajikan secara audio visual dalam film (Pratista, 2008: 33).

Film Mursala bercerita mengenai adat budaya Batak yang diperankan oleh Anggiat. Anggiat adalah seorang pemuda yang berasal dari Desa Sorkam Kabupaten Tapanuli Tengah. Anggiat berperan sebagai tokoh pemuda Batak yang berasal dari Desa Sorkam dan merantau ke Kota Jakarta untuk menggapai cita-citanya sebagai pengacara. Perjuangan Anggiat tidak sia-sia karena di Jakarta Anggiat berhasil menjadi pengacara yang sukses. Selain sukses dalam berkarir, Anggiat juga sudah mempunyai kekasih yang juga berketurunan Batak yaitu Clarisa Saragih. Namun, persoalan atau pertentangan muncul karena Anggiat dan Clarisa memiliki marga yang termasuk dalam parna (kumpulan marga yang tidak dapat menikah). Sedangkan inang (ibu Anggiat) sendiri ingin putranya menikah dengan Pariban-nya yaitu Tarulli Sinaga yang berada di kampungnya. Film Mursala sendiri bergenre drama, yang pada dasarnya drama berarti pencerminan dalam kehidupan manusia di masyarakat. Cerita kehidupan dalam masyarakat tentunya manusia memiliki permasalahan-permasalahan ataupun pertentangan-pertentangan baik fisik maupun psikis dalam hal ini adalah Anggiat yang ingin menentang adat larangan menikah se-marga.

Tokoh utama dalam film memiliki tujuan yang ingin dicapai, baik harapan maupun cita-cita. Tujuan dan harapan tersebut dapat bersifat fisik (materi) maupun nonfisik (nonmateri) (Pratista, 2008: 44). Tujuan yang ingin dicapai oleh tokoh utama dalam film Mursala yaitu Anggiat adalah dapat mempertahankan kekasihnya Clarisa Saragih dan menikah dengannya tanpa menyakiti keluarganya. Pencapaian suatu tujuan tidaklah mudah karena setiap perjuangan dalam pencapaian tujuan terselip persoalan-persoalan yang membuat tokoh utama tidak mudah mencapai tujuannya. Persoalan-persoalan yang dihadapi Anggiat ternyata tidak membuatnya dapat mempertahankan Clarisa. Anggiat tidak mendapatkan solusi atas permasalahan tersebut dan gagal mempertahankan Clarisa dihadapan adat.

\section{B. Unsur Sinematik}

Unsur naratif dapat dikatakan sebagai pembentuk cerita, sedangkan unsur sinematik adalah semua aspek teknis dalam produksi sebuah film. Dengan kata lain, unsur naratif diibaratkan sebuah nyawa sedangkan unsur sinematik adalah tubuh atau fisiknya. Unsur sinematik sama pentingnya dengan unsur naratif, karena unsur sinematik inilah yang membuat sebuah cerita menjadi sebuah karya audio visual berupa film. Unsur sinematik meliputi:

\section{1) Mise-en-scene}

Mise-en-scene dapat mudah dikenali karena seluruh gambar yang tampil di layar kaca film adalah bagian dari unsur ini. Mise-en-scene terdiri dari empat aspek utama, yaitu: a. Setting (Latar)

Film Mursala mengambil setting cerita pada dua lokasi yaitu di Tapanuli Tengah dan Jakarta. Hal ini tentu disesuaikan pula dengan isi cerita pada film Mursala 
yang mengemukakan adat Batak dengan menunjukkan tokoh pemuda Batak desa yang merantau ke kota metropolitan seperti Jakarta. Perbedaan antara kedua kota tersebut seolah sutradara ingin memberikan penjelasan kepada penonton mengenai perspektif yang ada pada masyarakat Batak di pedesaan dengan masyarakat Batak yang sudah berada di kota. Hal tersebut terlihat pada isi cerita film Mursala antara tokoh Anggiat dengan keluarganya dan tokoh Clarisa. Tetapi tidak hanya itu, beberapa setting kebanyakan di ambil di daerah Tapanuli Tengah dengan mengeksplor daerah-daerah wisata yang menonjol di Tapanuli Tengah seperti Pantai Binasih, Pulau Mursala (yang dijadikan nama film Mursala), Air Terjun Mursala, Pulau Puteri, Pulau Pandan, Sibolga, Makam Papan Tinggi dan lain sebagainya.

b. Kostum dan Tata Rias Wajah (make-up)

Film Mursala bercerita mengenai budaya Batak, tentu kostum dan rias yang digunakan disesuaikan dengan tema pada film tersebut yaitu adat Batak. Kostum dan tata rias yang paling menonjol pada film Mursala terlihat pada sekuen II. Terlihat pada sekuen tersebut para pemain menggunakan kostum adat Batak lengkap dengan tarian dan musik pengiringnya. Akan tetapi, terlihat berbeda dengan pakaian yang digunakan Clarisa yang juga berketurunan Batak. Hal tersebut menunjukkan bahwa budaya Clarisa telah bercampur dengan budaya yang ada ditempat tinggalnya. Berikut capture scene 25 yang memperlihatkan kostum dan tata rias pada film tersebut:

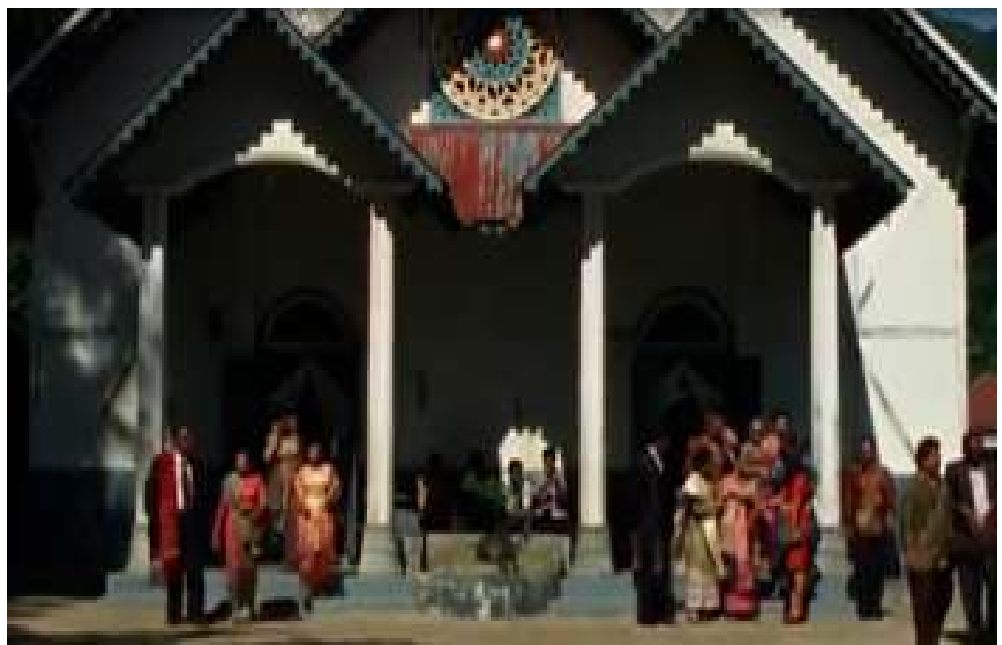

Gambar 2. Anggiat dan Keluarga menggunakan kebaya dan ulos di depan Gereja

(Sumber. Sri Wahyuni. Capture film Mursala. 2017)

c. Pencahayaan, Pemain dan Pergerakannya

Teknik pencahayaan dalam film Mursala kebanyakan menampilkan setting dengan konsep eksterior pantai-pantai Tapanuli Tengah dan dilakukan pada siang hari sehingga sumber cahaya yang digunakan adalah cahaya alami yaitu matahari sebagai key lightnya. Matahari dapat menimbulkan bayangan hitam, maka dari itu reflector biasanya digunakan untuk membunuh bayangan yang terlalu hitam.

d. Pemain dan Pergerakannya

Karakter yang dibawakan oleh Rio Dewanto sebagai Anggiat Simbolon dan selaku tokoh utama dalam film Mursala telah menguatkan isi cerita, dengan berlogat Batak dan sedikit lantang Rio mampu merealisasikan tokoh Anggiat sebagai pemuda 
Batak meskipun pada dialog Rio masih terlihat sedikit terbata-bata. Begitu juga dengan karekter-karakter tokoh lain, namun ada sedikit kelemahan pada karakter tokoh Clarisa Saragih yang diperankan oleh Anna Sinaga. Anna Sinaga berperan sebagai kekasih Anggiat yang berasal dari suku Batak tetapi menetap di Kota Jakarta. Pada scene 12 di menit sembilan Clarisa (Anna Sinaga) memperkenalkan karakternya sebagai kekasih Anggiat. Namun, acting Anna Sinaga masih terlihat kaku dan terlihat kurang mendapatkan chemistry layaknya pasangan kekasih. Selain Anna Sinaga, karakter Inang yang diperankan oleh Dra. Reiny ch Situmeang juga terlihat kaku dan kurang menjiwai karakter Inang. Karakter menonjol yang mampu diperankan dengan baik terlihat dari karakter uli (Titi Rajo Bintang) dan bapak Uda (Tio Pakusadewo) dengan cara berbicara yang baik layaknya orang Batak.

\section{2) Sinematografi}

Film pada umumnya menggunakan teknik sinematografi yang berfungsi sebagai teknik menangkap gambar dan menggabungkannya menjadi rangkaian gambar yang dapat menyampaikan ide cerita. Teknik tersebut terdapat pula pada film Mursala yang membentuk sebuah estetik dalam seni visual (film) yang memiliki makna. Salah satu capture gambar yang menunjukkan estetik dari film Mursala terlihat pada saat sutradara memperlihatkan pantai-pantai dan pulau-pulau di Tapanuli Tengah. Hal tersebut seakan sutradara memberikan ikonitas dari Tapanuli Tengah yang memeliki brand image "Kawasan Minopolitan Negeri Wisata Sejuta Pesona". Salah satu capture dalam film tersebut terlihat pada gambar sebagai berikut:

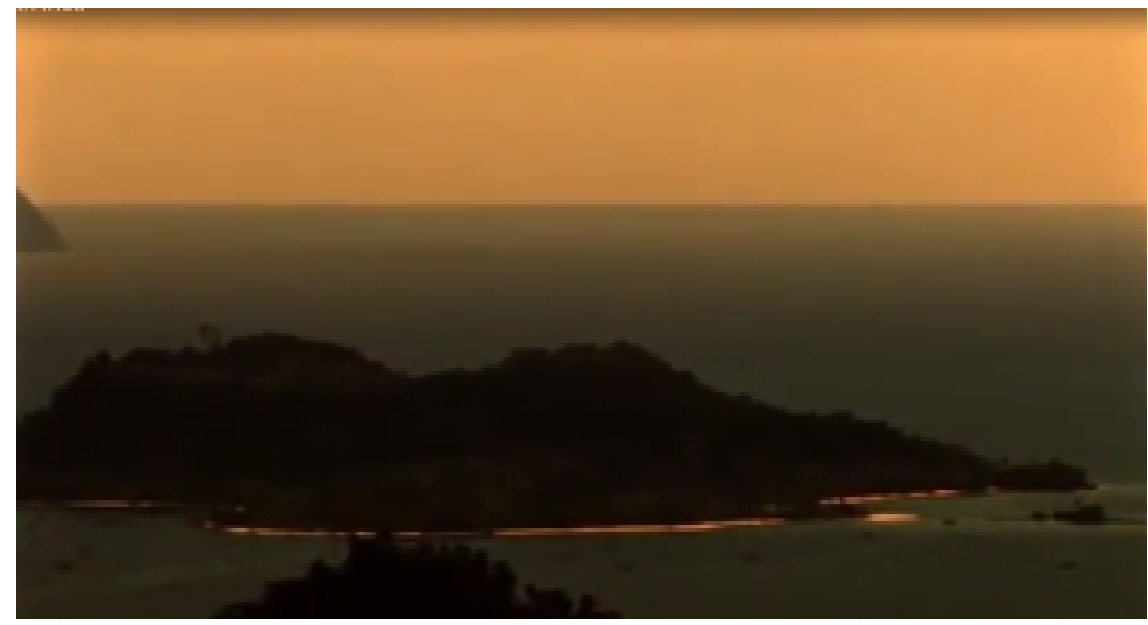

Gambar 3. Pemandangan Tapanuli Tengah

(Sumber. Sri Wahyuni. Capture film Mursala. 2017)

\section{3) Editing}

Tahap ini shot-shot yang telah diambil dipilih, diolah, dan dirangkai hingga menjadi satu rangkaian kesatuan yang utuh. Editing yaitu proses pemilihan serta penyambungan gambar-gambar yang telah diambil pada saat produksi, sementara editing pada saat pasca produksi merupakan teknik-teknik yang digunakan untuk menghubungkan tiap shot-nya. Pada tahap editing biasanya seorang editor akan menggambungkan potongan gambar shot ke shot sehingga gambar-gambar tersebut membentuk satu kesatuan (sekuen) dalam sebuah film (film Mursala). Beberapa transisi juga digunakan dalam film Mursala untuk menghubungkan satu kesatuan tersebut. 


\section{4) Suara}

Merupakan seluruh suara yang keluar dari gambar (film), yang dapat dikelompokkan menjadi tiga jenis yaitu dialog, music dan efek suara (Pratista, 2008: 61-149). David Brodwell menjelaskan dalam bukunya bahwa suara atau sound yaitu:

Sound is a powerfull film technique for serval reason. For one thing, it engages a distinct sense mode.

Suara adalah teknik film yang sangat kuat karena beberapa alasan. Untuk satuhal, ini melibatkan mode rasa yang berbeda (Brodwell \& Thompson: 2004: 348).

Melalui suara pesan yang akan disampaikan dalam film kepada penonton menjadi lebih mudah. Penonton dapat menangkap pesan dengan adanya unsur suara tersebut untuk mendukung pencapaian pesan yang ingin di sampaikan oleh penonton.

\section{Konsep Budaya Batak dilihat dari Pemaknaan Tanda dan Penanda}

Film pada prinsipnya sangat berhubungan dengan simbolik yang berisikan tentang makna-makna melalui tanda dan penanda yang ada pada film tersebut. Menurut Sobur, film merupakan bidang kajian yang amat relevan bagi analisis struktural atau semiotika. Film dibangun dengan tanda semata-mata, dalam film juga menggunakan tanda-tanda ikonis yaitu tanda-tanda yang menggambarkan sesuatu. Rangkaian gambar dari film menciptakan imaji dan sistem penandaan. Ciri gambar-gambar film merupakan persamaannya dengan realitas yang ditunjuknya. Gambar yang dinamis dalam film merupakan ikonis bagi relitas yang dinotasikannya (Sobur, 2009: 128).

Sebagaimana yang dinyatakan oleh Sobur, film Mursala memiliki arti simbolis yang tidak terhitung jumlahnya. Bentuk cerita pada film Mursala menyimbolkan sesuatu yang konkrit dan mewakili. Untuk melihat konsep budaya batak dalam film Mursala diperlukan pemaknaan tanda pada film. Makna menurut Roland Barthes sebuah wahana tanda yang merupakan satuan kultural yang diperagakan oleh media-media tanda lain tentang relasirelasi tentang objek yang diacu (Roland Barthes, 1988:121). Dalam kehidupan sosial budaya pada masyarakat, penggunaan tanda pada film tidak hanya dimaknai sebagai denotasi (merujuk pada apa yang diyakini akal sehat atau orang banyak). Barthes menyebutkan bahwa denotasi sebagai signifikasi tahap pertama yaitu hubungan sebuah tanda dengan tanda yang mewakili sebuah realitasnya. Contoh pada film Mursala, selain sebagai seni tontonan yang dilihat sebagai hiburan seluruh masyarakat. Namun, penggunaan tanda dipakai untuk sebuah pengungkapan makna yang membentuk sebuah konsep cara masyarakat mewariskan adat leluhurnya salah satunya yaitu konsep budaya batak. Film Mursala menggambarkan larangan menikah se-marga atau se-namarpadan pada adat Batak. Orang Batak tidak dapat menikah dengan se-marga nya karena diyakini bahwa orang tersebut akan mendapatkan bala/celaka.

Pemakaian tanda tahap pertama tersebut mengembangkannya kedalam dua arah yaitu sistem tanda tataran kedua.Hal ini terjadi karena interaksi yang terjadi ketika tanda bertemu dengan perasaan atau emosi dari pengguna dan nilai-nilai dalam budaya memiliki makna yang berbeda.Nilai-nilai inilah yang ditandai Barthes sebagai mitos, yang merupakan sebuah cerita dimana suatu kebudayaan menjelaskan atau memahami beberapa aspek dari realitas atau alam. Film Mursala bukan hanya sekedar tontonan untuk hiburan pada masyarakat melainkan juga sebagai pengungkapan masyarakat Batak dalam mewariskan adat larangan menikah se-marga. Barangkali ada makna-maka lain yang diwakilkan sebuah tanda dalam film Mursala yang membentuk suatu konsep kebudaya batak dalam masyarakat Batak dan berkembang menjadi sebuah mitos. Berikut merupakan 
Bagan Makna menurut pandangan Roland Barthes yang telah di aplikasikan kepada film Mursala sebagai berikut:

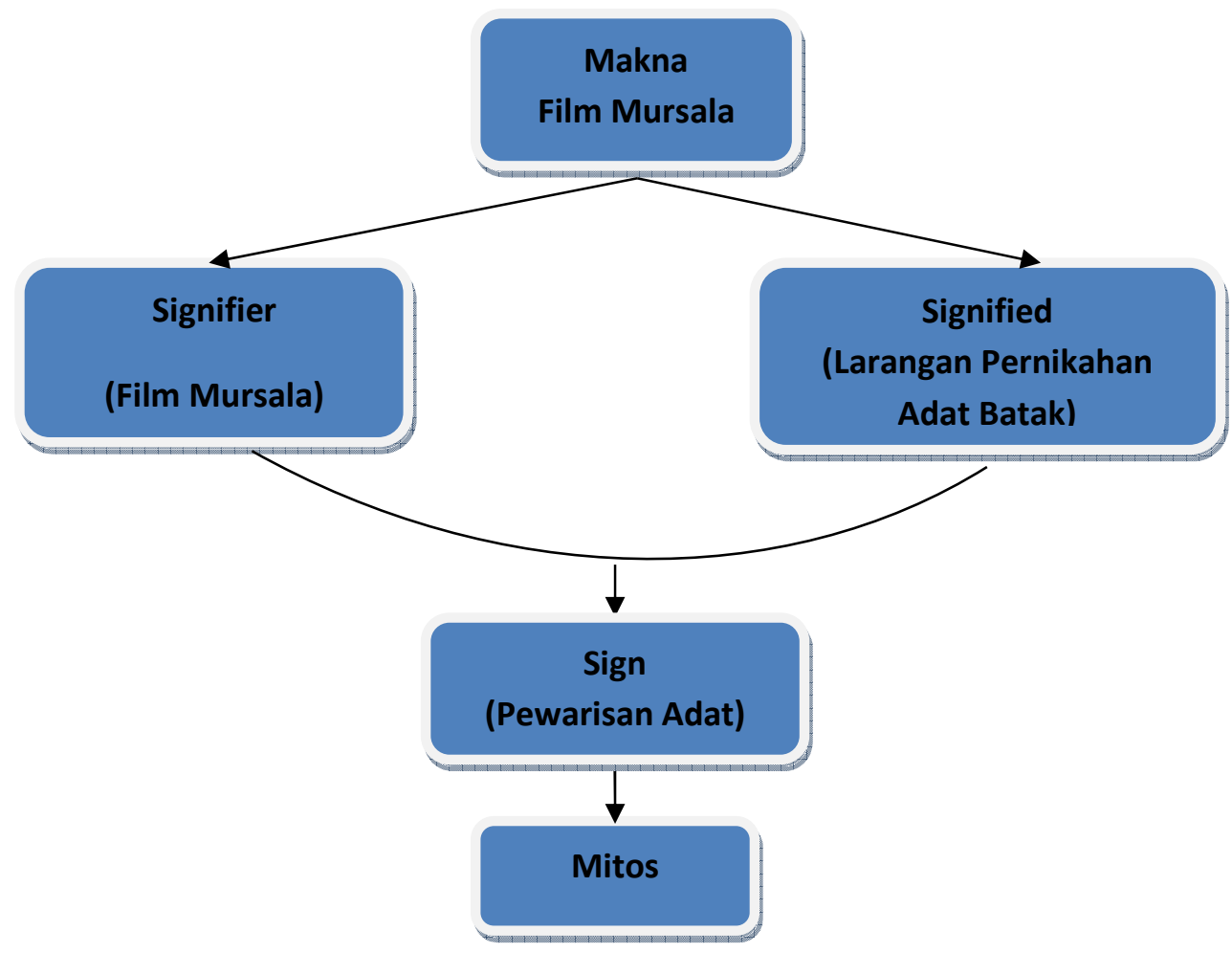

Gambar 4. Bagan Makna Film Mursala Menurut Pandangan Roland Barthes

(Sumber: Sri Wahyuni. 2017)

Tahap pemaknaan film Mursala tidak hanya dilakukan secara denotatif (secara umum) melainkan juga secara konotatif (pribadi) yaitu sebagai pewarisan adat pada masyarakat Batak yang dilihat dalam film Mursala. Makna tersebut dapat dilihat dalam film Mursala berdasarkan struktur pembentuk filmnya yang bersifat naratif dan sinematik, karena kedua struktur pembentuk film tersebut akan mempengaruhi makna yang ada dalam teks. Untuk melihat makna tersebut, para peminat film perlu lebih mendalami kedua unsur pembentuk film. Peransi menjelaskan bahwa:

Struktur merupakan blueprint kerangka desain yang menyatukan berbagai unsur film dan mempresentasikan jalan pikiran dari pembuat film. Struktur terdapat dalam semua bentuk karya seni.Pada film mengikat aksi (action) dan ide menjadi satu kesatuan yang utuh (Peransi, 2005: 8).

Struktur film tersebut akan mendukung petanda yang dimunculkan pada film Mursala menjadi realitas yang mengikat cerita pada kehidupan masyarakat Batak. Cerita yang disampaikan pada film Mursala tentu saja memiliki nilai-nilai budaya pada masyarakat Batak sebagai pendukung adat tersebut. Barthes menguraikan terdapat pola tiga dimensi dalam mitos yang disebut sebagai penanda, petandaan tanda. Hal tersebut dapat dilihat dari peta tanda Roland Barthes yang menjelaskan bahwa tanda denotative (3) terdiri atas penanda (1) dan petanda (2). Akan tetapi, pada saat bersamaan tanda denotative adalah juga penanda konotatif (4).

Setelah dilakukannya pemaknaan tanda dan penanda maka dapat diketahui konsep budaya batak terlihat jelas dalam film mursala yang dirangkai sedemikian rupa melalui aspek naratif dan sinematik sehingga membentuk satu kesatuan cerita dan visual yang 
mengungkapkan konsep budaya batak dalam film Mursala seperti keyakinan Inang terhadap pesan para leluhur Batak bahwasanya tidak diperbolehkannya pernikahan semarga seperti yang di perjuangkan oleh Anggiat dengan kekasihnya. Meskipun Anggiat telah berusaha untuk mempertahankan hubungannya dengan kekasihnya namun hubungan keduanya pada akhirnya berpisah. Hal ini jelas tergambar pada film Mursala, meskipun zaman sudah modern bahkan dalam film Mursala, Anggiat sudah hidup di kota besar namun segala pemikiran-pemikirannya tidak dapat mengubah adat yang sudah ada. Hal ini berarti, konsep budaya Batak masih sangat dipegang teguh atau eksis oleh masyarakat Batak hingga saat ini.

\section{Pandangan Masyarakat Batak Pada Film Mursala}

Untuk melihat pandangan-pandangan dari masyarakat Batak terhadap film Mursala maka dilakukan beberapa wawancara yaitu:

\section{a. Wawancara terhadap Ketua Lembaga Adat}

Kasnuddin (Ketua Lembaga Adat Dalihan Na Tolu) berpendapat dalam film Mursala terdapat cerita yang menggambarkan masyarakat Batak yang melarang adanya pernikahan se-marga ataupun melarang pernikahan berbeda marga tetapi terikat dalam satu ikrar janji (namarpadan) untuk tidak saling menikah oleh para leluhur terdahulu (Wawancara, 22 Mei 2017). Dalam masalah perkawinan di Sorkam (salah satu lokasi dalam film Mursala), terdapat larangan menikah antara orang-orang satu marga atau orang-orang yang terikat dalam ikrar janji (namarpadan) antar marga untuk tidak saling menikah. Hubungan antara orang-orang dalam satu marga atau yang terkena namarpadan dianggap sama dengan hubungan antara sesama saudara kandung, artinya menikah dengan saudara sendiri. Maka orang-orang Batak diharuskan untuk melakukan pernikahan dengan orang dari luar marga yang tidak termasuk dalam parna seperti menikahi pariban.

\section{b. Wawancara terhadap Pemuka Agama Kristen (Pena Tua Gereja)}

Kasnuddin Pandiangan selaku ketua adat sekaligus seorang pendeta di desa Pahieme kabupaten Tapanuli Tengah mengatakan bahwa segala sesuatu yang berkaitan dengan adat istiadat suatu suku budaya yang ada di masyarakat, selama adat istiadat tersebut tidak keluar dari norma agama dan tidak bertentangan dengan agama maka agama tidak mempersalahkannya. Didalam agama khususnya agama kristen tidak ada larangan pernikahan seperti larangan pernikahan se-marga atau larangan pernikahan semarpadan yang termasuk dalam parna, namun Kasnuddin menyebutkan bahwa meskipun demikian ada baiknya masyarakat juga mematuhi adat yang ada karena biasanya adat yang dibuat oleh para leluhur tidak akan menyalahi agama justru sebaliknya. Orang-orang yang mengikuti atau taat kepada adatnya secara tidak langsung juga taat kepada agamanya (wawancara : 22 Mei 2017).

\section{c. Wawancara terhadap Pemuda Batak di Desa dan Kota}

Cerita yang disampaikan dalam film Mursala mengenai 70 marga yang tidak boleh menikah akibat adanya namarpadan/padan (ikrar janji) oleh leluhur sampai saat ini ternyata masih dipegang teguh oleh masyarakat suku Batak.Hal ini terbukti dengan pernyataan Renhat Pasaribu, seorang pemuda yang berasal dari Desa Pahieme Kabupaten Tapanuli Tengah.Renhat menyebutkan bahwa sejak kecil biasanya kedua orang tua sudah menjelaskan mengenai pernikahan yang dilarang oleh adat dan sanksiyang diberikan jika melanggar adat, tidak hanya hal tersebut bahkan keluarga juga turut serta untuk menanamkan pengetahuan mengenai adat. Renhat mengatakan 
belum pernah melihat film Mursala sebelumnya, namun sempat mendengar nama filmnya dan mengetahui bahwa pengambilan gambar atau syutingnya di Desa Sorkam. Renhat sepakat dengan isi cerita yang terdapat dalam film Mursala dan menurutnya, film ini dapat memberikan wawasan terhadap masyarakat khususnya masyarakat Batak (Wawancara 20 Mei 2017).

\section{KESIMPULAN}

Film Mursala merupakan film bergenre drama dan berdurasi satu jam tiga puluh menit enam detik. Film Mursala karya Viva Westi mengangkat cerita budaya lokal yaitu budaya suku Batak. Cerita yang disampaikan dalam film Mursala memasuki daerah konflik sosial karena adanya larangan pernikahan dari leluhur Batak bahwa beberapa marga telah mengikat janji (marpadan) untuk tidak saling nikah, dan hingga saat ini adat tersebut masih dijalankan pada masyarakat Batak. Alur cerita tersebut berkaitan dengan realitas yang ada pada masyarakat Batak.

Konsep budaya batak dalam realitas masyarakat yaitu sesuai dengan sistem kekerabatan dalam Dalihan Na Tolu. Peran dalam Dalihan Na Tolu akan menjadi tumpang tindih atau tidak jelas jika ada perkawinan se-marga atau parna yang mengakibatkan pihak perempuan tidak bisa menentukan mana pihak Parboru ( saudara perempuan) dan pihak Paranak pada setiap acara adat termasuk acara adat perkawinan. Maka, Salah satu konsekuensi dari Dalihan $\mathrm{Na}$ Tolu adalah larangan menjalin ikatan perkawinan atau pernikahan bagi perempuan dan laki-laki yang mempunyai marga yang sama.

Berdasarkan grafik responden yang telah didapat menurut pandangan masyarakat Batak bahwa 50\% dari keseluruhan responden setuju dan $48 \%$ menyatakan sangat setuju jika marpadan tetap dipertahankan hingga saat ini. Sementara itu, hanya $2 \%$ responden yang menyatakan tidak setuju jika adat tersebut tetap dijalankan. Sedangkan 0\% untuk hasil sangat tidak setuju apabila adat tersebut dijalankan. Maka dapat disimpulkan bahwa masyarakat Batak masih sangat setuju jika adat tersebut masih dijalankan hingga kini. Hal itu didapatkan dari hasil kuesioner yang dibagikan kepada responden yang diasumsikan melalui penggambaran pada sebuah film yaitu film Mursala.

\section{DAFTAR PUSAKA}

[1] Barthes, Roland.2007.Petualangan Semiologi (Diterjemahkan oleh Sthepanus Aswar Herwinarko dari L'aventure Semilogique)

[2] -----------------. 1972. Mytologies. New York. The noonday Press.

[3] Ristiawan Moleong, Lexy J., Metodologi Penelitian Kualitatif, Bandung: Rosda karya, 2013.

[4] Nawawi, Hadari. 1983. Metode Penelitian Bidang Sosial.Yogyakarta: Gajah Mada University Press.

[5] Pratista, Himawan. Memahami Film. Yogyakarta: Homerian Pustaka, 2008.

[6] Sugiono., Memahami Penelitian Kualitatif. Bandung: ALfabeta, 2012. 